\title{
Advocacy coalition formation and key actors within the policy
}

\author{
Diana Cruz Rodrigues ${ }^{1}$
}

Mário Vasconcellos Sobrinho 12

Ana Maria de Albuquerque Vasconcellos 1

1 Universidade da Amazônia / Administration Postgraduate Program, Belém / PA - Brazil

2 Universidade Federal do Pará / Natural Resource Management and Local Development Postgraduate Program, Belém / PA Brazil

The article discusses advocacy coalition formation and the roles of key actors in science, technology and innovation (ST\&I) policies for social inclusion in a subnational context. The policy subsystem category and concept of advocacy coalition are used in the context of the advocacy coalition framework and address the need to understand the influences of key actors (policy broker and policy entrepreneur) on it. The policy subsystem was outlined using case-oriented research and the discourse was analyzed in order to understand the policy actors' beliefs. The analysis of two cases of ST\&I policy processes for social inclusion (assistive technology and social technology) highlighted policy broker and policy entrepreneur key roles in the emergence of policy subsystems, but had different effects on advocacy coalition formation. The policy entrepreneur had a closer relationship with advocacy coalition building when setting up regular mechanisms to share beliefs and policy-oriented learning, as well as taking initiatives to coordinate the collective action of members in the early advocacy coalition. Although relevant in agenda setting and maintaining a specific social inclusion agenda in the policy process, the policy broker did not achieve a positive relationship with advocacy coalition building. The article corroborates the possibility of incorporating the concept of policy entrepreneur in analyses of the advocacy coalition framework and highlights this actor's characteristics through this analytical model.

Keywords: policy process; advocacy coalition framework; public policy of science and technology for social inclusion; social technology; assistive technology.

\section{Formação de coalizão de defesa e atores chaves da política}

O artigo discute a formação de coalizão de defesa e o papel de atores chaves em políticas de Ciência, Tecnologia e Inovação (CT\&I) para inclusão social em um contexto subnacional. No âmbito do Modelo de Coalizão de Defesa (MCD), utilizou-se as categorias analíticas do subsistema da política e da coalizão de defesa como referência e buscou-se compreender as influências de atores chaves nestas, especificamente o policy broker (mediador) e o empreendedor de política. O subsistema de política foi delimitado pelo método de pesquisa baseada em caso e a análise de discurso foi mobilizada para compreender as crenças dos atores da política. A análise de dois casos do processo de política de CT\&I para inclusão social (tecnologia social e tecnologia assistiva) realçou os papéis de atores chaves na emergência dos subsistemas de política, porém estes tiveram diferentes efeitos sobre a formação de coalizões de defesa. O empreendedor da política teve maior relação com a formação de coalizão de defesa ao estabelecer mecanismos regulares para compartilhamento de crenças e aprendizados orientados para a política, bem como ao tomar iniciativas de coordenação da ação coletiva na coalizão de defesa nascente. O policy broker não alcançou relação positiva substancial com a formação das coalizões de defesa analisadas, embora tenha sido relevante para o agenda-setting e a permanência da pauta de inclusão social no processo da política. O artigo corrobora com a possibilidade de incorporação do conceito de empreendedor de política em análises do MDC e aponta características deste ator chave iluminadas pelo modelo analítico.

Palavras-chave: processo de políticas públicas; modelo de coalizão de defesa; política pública de ciência e tecnologia para inclusão social; tecnologia social; tecnologia assistiva. 


\section{Formación de coaliciones de defensa y actores clave dentro de la política}

El artículo analiza la formación de coaliciones de defensa y los roles de los actores clave en las políticas de ciencia, tecnología e innovación (PCTI) para la inclusión social en un contexto subnacional. Considerando el modelo de coalición de defensa (MCD), se utilizaron como referencia las categorías analíticas del subsistema de la política y de la coalición de defensa, para comprender las influencias de los actores clave, específicamente del policy broker (intermediario) y del emprendedor de políticas. El subsistema de la política se delimitó mediante el método de investigación basado en casos y se usó el análisis del discurso para comprender las creencias de los actores en la política. El análisis de dos casos del proceso de la PCTI para la inclusión social (tecnología social y tecnología de la rehabilitación) resaltó los roles de los actores clave en la aparición de subsistemas de la política, sin embargo tuvieron diferentes efectos en la formación de coaliciones de defensa. El emprendedor de políticas tuvo una mayor relación con la formación de una coalición de defensa al establecer mecanismos regulares para comunicar sus posiciones y aprendizajes orientados a la política, así como al tomar iniciativas para coordinar la acción colectiva en la naciente coalición de defensa. El policy broker no logró una relación positiva con la formación de las coaliciones de defensa analizadas, pero sí fue relevante para el establecimiento de la agenda y la permanencia de la pauta de inclusión social en el proceso de la política. Este trabajo corrobora la posibilidad de incorporar el concepto de emprendedor de política en los análisis de MDC y señala las características de este actor clave en el modelo analítico estudiado.

Palabras clave: proceso de políticas públicas; modelo de coalición de defensa; política pública de ciencia y tecnología para la inclusión social; tecnología social; tecnología de la rehabilitación.

\section{INTRODUCTION}

The article addresses advocacy coalition formation and the role of key actors for emerging marginal themes in the public policy process based on the advocacy coalition framework (ACF) (Jenkins-Smith, Nohrstedt, Weible, \& Ingold, 2017; Sabatier \& Jenkins-Smith, 1993; Weible, Sabatier, \& McQueen, 2009). Science, technology and innovation (ST\&I) policy processes are specifically analyzed in a subnational context, particularly the processes referring to promoting social technology (ST) and assistive technology (AT) in the Pará state government in northern Brazil.

In Brazil, guidelines related to science and technology ( $\&$ \& $)$ for social inclusion appeared in the federal ST\&I policy agenda in the early 2000s, at that time mostly tied to the S\&T Secretariat for Social Inclusion (Secis) (Dias, 2012). Although they maintained a marginal position on the ST\&I agenda, initiatives in different topics were taken, such as assistive technologies and social technologies.

Assistive technology (AT) refers to the development of resources for persons with disabilities or reduced mobility who seek to maintain or improve their autonomy and promote their own wellbeing (MacLachlan et al., 2018). Social technology (ST) covers products, techniques or methodologies developed with the participation of local communities that seek their own social transformation (RTS, 2010). ST is frequently related to meeting basic needs and improving the quality of life for vulnerable social groups.

The state of Pará is on the periphery of the ST\&I policy context in Brazil, with low levels of investments. The northern region where the state is located also has the lowest overall ST\&I indicators in Brazil (Cavalcante, 2011; Theis, Strelon, \& Lasta, 2017). Those conditions keep marginal issues such as S\&T for social inclusion from moving up on the agenda.

Thus on the ST\&I agenda for Pará, AT and ST policies only began to emerge beginning in 2011. The relatively recent rise of these issues on the state agenda, with a considerable lag behind their 
appearance on the national agenda, have led us to more carefully examine internal elements of the subnational policy process that were decisive for that change and the placement of these issues on the agenda, despite the existence of limiting conditions in the peripheral context, and keeping them in the policy process, albeit marginally.

In this scenario, we seek to analyze the trajectory of AT and ST issues in the subnational ST\& I context in Pará, from 2011 to 2018, using ACF with a focus on forming local advocacy coalitions and key actors.

Among the key actors we selected the policy broker, already provided in ACF since the seminal publication of Sabatier and Jenkins-Smith (1993) and the policy entrepreneur. The relevance of the analysis of a more diverse group of key actors in the study of advocacy coalitions, including the policy entrepreneur, was recently highlighted in Weible, Ingold, Nohrstedt, Henry, and Jenkins-Smith (2019). Analyses of the role of the policy entrepreneur in advocacy coalitions were discussed initially in Mintrom and Vergari (1996) and in some later publications such as Mintrom and Norman (2009) and Belánd and Cox (2015).

Although the role of policy entrepreneur has not yet been incorporated in the assumptions of broader reviews of ACF (Jenkins-Smith, Nohrstedt, Weible, \& Sabatier, 2014; Jenkins-Smith et al., 2017; Weible et al., 2009), the publications cited demonstrates that analyzing may be promising in the context of ACF, particularly in elucidating processes for building of advocacy coalitions and rapid changes in the policy process.

Therefore, this article seeks to discuss the formation of advocacy coalitions and the role of key actors (policy broker and policy entrepreneur) in them, as elements that promote changes in the policy process. This is true particularly because of the rise of social inclusion issues in the ST\&I policy process and their resistance processes in order to remain on the agenda, even if marginally, thus making change more palpable.

In applied terms, we also seek to contribute to ST\&I policy studies in subnational contexts in Brazil, particularly those that are peripheral. This favors generation of knowledge for changes moving towards more endogenous drafting of ST\&I policies at subnational levels, and also federal-level coordination that is more sensitive to regional specificities and asymmetries.

\section{ADVOCACY COALITION FRAMEWORK}

The advocacy coalition framework (ACF) emerged in the 1980s in groundbreaking studies by Paul Sabatier and Hank Jenkins-Smith (Sabatier \& Jenkins-Smith, 1993). The framework follows a cognitive approach to the policy process, in which the actors' rationale focuses on variables relating to ideas, beliefs and knowledge (Faria, 2003; Jenkins-Smith et al., 2017).

The ACF stresses a holistic view of the policy process, in which politics are permeated with disputes of the actors' beliefs and ideas about defining public problems, their causes, alternative solutions and forms for monitoring and evaluation. Successful ideas and beliefs in such disputes shape the policy, and are reflected in its objectives, preferential designs and in the content of a policy domain.

This article focuses on the policy subsystem category and the concept of advocacy coalition and the role of actors in key positions of the policy. The policy subsystem is the main analytical unit of the ACF where the policy actors operate and organized possibly in advocacy coalitions through their 
beliefs and resources. These actors define strategies to influence governmental decisions (institutional rules, resources allocation, appointments), as well as public policy products and results (JenkinsSmith et al., 2014).

The concept of the policy subsystem is that of a group of actors involved in a policy problem who interact systematically to influence the contents and directions of this policy (Sabatier \& JenkinsSmith, 1993). The scope of the subsystem is demarcated by mapping the actors (and their possible organizations) that seek to influence a policy process.

The policy actors in the ACF are not restricted to what is referred to as the "iron triangle" (legislators, government agencies and groups of stakeholders) (Weible et al., 2019). The view concerning potential actors extends to those seeking to influence the policy process, including, for example, researchers, consultants, journalists and persons working in the legal system (Capella \& Brasil, 2015).

Advocacy coalitions for their part are a group of actors sharing essential beliefs in the policy scope and coordinating their actions in no trivial manner, in order to influence the policy's subsystem (Sabatier \& Jenkins-Smith, 1993; Jenkins-Smith et al., 2017).

Bringing together policy actors in advocacy coalitions involves two main characteristics in its original concept: sharing beliefs and coordinating actions. Of these characteristics, the belief system continues as an element structuring the coalition composition, and is the collective coordinating element associated with and conditioned to the former (Leifeld, 2013).

The notion of belief system of the ACF is based on a hierarchical structure consisting of three levels (Box 1).

BOX 1

BELIEF SYSTEM LEVELS OF ADVOCACY COALITIONS

Belief levels
$\begin{aligned} & \text { The broadest and most stable beliefs referring to general normative and ontological values } \\ & \text { applicable across many subsystems. Examples include beliefs related to policy projects (liberal or } \\ & \text { conservative beliefs) }\end{aligned}$
$\begin{aligned} & \text { Normative and empirical guidelines compatible with the specific policy subsystems. The normative } \\ & \text { concepts are related to basic guidelines and priority values; and the empirical concepts to the } \\ & \text { analyses regarding policy problems, proposed causes and alternative solutions. These beliefs are } \\ & \text { an intermediary level, yet hard to change, and more likely to be adapted than the deep beliefs }\end{aligned}$
$\begin{aligned} & \text { Policy core beliefs } \\ & \text { Guidelines on a thematic subsystem or specific instrumental means of decision, implementation } \\ & \text { aspects }\end{aligned}$
$\begin{aligned} & \text { or control in the policy subsystem. They are narrower in scope, predominantly based on empirical } \\ & \text { experiences, and more likely to be learned and changed }\end{aligned}$

Source: Adapted from Weible, Sabatier, and McQueen (2009). 
The hypotheses of differentiation and hierarchical relation to the belief system and its effects on the coordination of activities are maintained in more recent revisions of the ACF (Jenkins-Smith et al., 2017) and of the advocacy coalition concept (Weible et al., 2019). However, some applied research has demonstrated a methodological problem in distinguishing them and actually found no empirical support for such hierarchical belief structure. This is why the authors comment that is possible to combine policy core beliefs and secondary aspects, depending on the focal scope of the research. This integrated perspective (non-hierarchical) was adopted in this study.

Despite the prevalence of the analysis of the belief system in ACF applications, Weible et al. (2019) also stress the importance of the systematic analysis of conditions and attributes of coordinating the actors to understand the modus operandi of coalitions.

An ideal type of advocacy coalition proposed by Weible et al. (2019) considers the existence of actors in the policy process that (a) share beliefs, (b) coordinate their actions and (c) systematically exercise these characteristics over time. From this ideal type, the authors examine the absence of attributes as different forms of composition of advocacy coalitions, such as the ephemeral (whose collective coordination does not become regular over time) or potential or disconnected (with no coordination).

To refine the analysis of advocacy coalitions, Weible et al. (2019) propose five attributes: policy actors, belief systems, coordination of political activities, resources and stability. We understand that this analysis of attributes in advocacy coalitions contributes with one of the previously highlighted points in the ACF research agenda, indicated by Jenkins-Smith et al. (2014), in terms of examining how the advocacy coalition forms and how its stability develops in the long run.

\subsection{Advocacy coalition and key actors in the policy change process}

Understanding long-term change processes in public policies was one of the original analytical focuses in the ACF proposal. For the framework, the advocacy coalitions generally assume protagonism for such changes or stability in a policy subsystem (Sabatier \& Jenkins-Smith, 1993).

Jenkins-Smith et al. (2017) uphold four proposals regarding changes in the ACF:

(1) those arising from external alterations or disturbances of both relatively stable parameters and dynamic events;

(2) those based on internal events and actions of actors in the subsystem;

(3) those caused by learning processes focusing on policy; and

(4) those promoted by agreements negotiated between coalitions previously strongly opposed to each other, generally facilitated by intermediary organizations.

At least one of these paths is considered necessary for changing the policy, but the actual occurrence of one of them on its own is normally not enough, and a combination of them is required in processes of change (Jenkins-Smith et al., 2017).

Among the sources of changes are policy-oriented learning processes, another analytical focus at the origin of ACF. Jenkins-Smith et al. (2014) associate the learning processes with reinforcing or 
requiring revision of precepts of the belief systems of actors in a coalition. These learning processes have implications regarding not only problems and solutions that should be directed to the policy subsystem, but also strategies and instruments to be used to achieve objectives.

Jenkins-Smith et al. (2017) list four factors that influence the learning processes of the policy actors in the ACF: (1) level of conflict in the subsystem; (2) existing incentives for acquiring knowledge; (3) attributes of the actors (extreme or moderate beliefs, resources of access to information, strategies) and attributes of forums and others interacting spaces. For the last item, we emphasize one of the hypotheses of the framework, that policy-oriented learning is more likely to develop when there is a professional discussion forum in the subsystem that is (a) prestigious enough to force members of different coalitions to participate and (b) regulated by professional standards (Weible et al., 2009).

Although the policy-oriented learning from the original ACF hypotheses are more oriented to analysis of the policy process itself, we consider that they may be specifically relevant to the formation and development of advocacy coalitions. This is because learning processes may impact the building of consensuses and disseminations of a coalition that is being formed, as well as on creating mechanisms for mobilization and internal collective coordination.

Béland and Cox (2015) have emphasized the role of disseminating idea and of mobilizing support of different groups in order to building coalitions. Those authors note that these themes tend to be polysemic and the policy entrepreneur's role is to be the person responsible for promoting those ideas and mobilizing supporters, resulting in the forming of coalitions.

The policy entrepreneur category is more evident in other policy frameworks, especially in the Multiple Streams Framework (Kingdon, 2014). This category was not originally developed in the ACF, but Mintrom and Vergari (1996) had already postulated the possibility of its inclusion to refine the framework. For Mintrom and Vergari (1996) the concept of policy entrepreneur would particularly cast light on the analysis of advocacy coalition formation (member composition and coordination) and provide more details on how and when critical changes occur.

Later on, Mintrom and Norman (2009) made advances in defining policy entrepreneurs by pointing out four key performing elements of the policy entrepreneurs: demonstrating social acuity, defining problems, building teams and leading by example. These authors believe the integration of the concept of policy entrepreneur in analytical policy frameworks can offer more comprehensive views of the many factors involved in change processes.

Capella (2016) sought to explore the role of policy entrepreneur in several analytical models. Among these she included ACF. Although ACF did not specifically define the role of policy entrepreneur, the author highlighted the relations of the entrepreneur with functions related to forming coalitions and idea-based learning processes. She highlighted two basic dimensions in the work of entrepreneurs: advocacy of ideas in the policy process and conducting processes for rapid changes in policies.

Weible et al. (2019) cite policy brokers and policy entrepreneurs among the different actors and possible members of advocacy coalitions. Originally, the ACF had already highlighted the category of policy brokers. Policy brokers are actors generally employed in elective positions or 
top public servants in the policy, whose main concern was to keep the level of political disputes in the subsystem at acceptable limits and, when necessary, attempted to negotiate reasonable solutions between opposing coalitions (Sabatier \& Jenkins-Smith, 1993). However, Sabatier and Jenkins-Smith (1993) point out that, regardless of the performance as policy brokers, those individuals could also be members of an advocacy coalition or express more favorable attitudes to a certain coalition.

In this article, we seek to focus on the actions of those actors (policy broker and policy entrepreneur) at the specific moment of the process of forming coalition. We intend to explore, observe and describe the roles performed, in terms of defending ideas, setting up beliefs and conduction processes for learning and dissemination, construction of mechanisms for coordination political activities, accumulation of resources and stability in action.

\section{METHODOLOGY}

To analyze the trajectory of AT and ST policy processes in the subnational government of Pará (Brazil), we used the case-oriented research method (Ragin, 1992, 2009), with a qualitative approach. The "casing" methodological process was used to operationalize the policy subsystem category, the main analytical unit in ACF. According to Ragin $(1992,2009)$, casing refers to the methodological step of establishing (delimiting and declaring) research cases, using the procedural "fit" of theoretical and conceptual categories with the empirical evidence and specific points of the phenomenon.

To delimit the cases of AT and ST policy processes to the concept of a policy subsystem, we performed casing in two stages: the first involving an overall view of the state ST\&I policy in Pará; and the second to specifically delimit the policy processes linked to AT and ST issues.

In the first stage, we used the conventional notion of federative unit of the state of Pará and policy organizations situated therein as a geographical guideline. We focused on the organizations and actors involved in the policy process associated with ST\&I. The three main organizations identified were the state secretariat responsible for ST\&I domain, the state research support foundation [Fundação de Amparo à Pesquisa (FAP)] and Pará State University (UEPA).

In this first stage, data collection focused on document research on the last three pluriannual plans (PPA) in Pará (from 2008 to 2017), specifically focusing on programs related to the ST\&I portfolio (thematic search) and programs in which the three key organizations participated (search for governmental organizations). We also performed document analyses of the ST\&I master plans, guidelines and funding instruments (calls and public funding) for the same period. Furthermore, we made exploratory visits to public employees of the three main organizations identified. Based on that research we identified issues of social inclusion that made it to the agenda and were implemented in the policy process and with its major actors.

The second stage of demarcation of the two policy subsystems (AT and ST) covered the mapping of the main actors involved in the policy process of these topics. Based on this, we examined the pathway of policy process and identified policy actors in key roles and possible formation of local advocacy coalitions. The period of analysis of these topics included their emergence on the ST\&I state agenda (2011) until 2018. 
Data collection in this second phase involved new documentary research and semi-structured interviews. The documentary research covered financing of projects and activities related to AT and ST through the State Secretariat of the ST\&I and the FAP. The documentation researched was on funding instruments, the respective projects funded and their technical reports, as well as the administrative procedures linked to them and thematic events held in the state.

After the documentary research, semi-structured interviews were held with directors of the State Secretariat and FAP, employees of those organizations involved in processes for formulating public policy and evaluation of the projects, coordinators of the funded projects and three researchers reported to be locally influential. Interviews were thus held with 18 actors related to AT and 13 actors to ST, from September 2018 to January 2019.

Based on the document analysis and the interviews timelines were organized with the milestones from the policy processes (AT and ST), which served as the basis for a longitudinal view of the cases relevant for a long-term analysis of ACF and a descriptive reconstruction of each trajectory (presented in the following sections).

Additionally, we also analyzed the belief systems of the actors in each policy subsystem (AT and ST). Beliefs of the actors were analyzed using the discourse analysis method. Although content analysis was originally the most common method in ACF, Jenkins-Smith et al. (2014) highlighted the need to be open to a broader methodological orientation with approaches involving representation of the world or ideological aspects in policy.

In this study, analysis of the discourse in each technology policy process (AT and ST) sought to identify the preferences and positions of the actors in terms of 6 established categories: (1) Main focus of technological development, (2) concept of technology, (3) who produces knowledge and technology in society, (4) who are the protagonists of the policy at issue, (5) implementation strategy, and (6) technological dissemination.

\section{RESULTS AND ANALYSIS}

\subsection{ST\&I State Policy in Pará and Incentive for Assistive Technology and Social Technology}

Based on the analysis of the documentary sources for the ST\&I state policy process in Pará in the period 2008-2017, we found a incremental process around the innovation system concept (Pará Innovation System). This concept highlights the role of the technological innovation policy in generating development for the state, with emphasis on its economic dimension, according to examples of documentary extracts below.

To reinforce the economy by attracting industrial plants and development of innovative goods in environments such as: industrial districts and sites, corporate incubators, science and technology parks (Pará, 2007, p. 90).

Consisting of organizations, people, instruments and processes, the Pará Innovation System (SPI) aims to engage Pará State in the new strongly knowledge-based global economy and is configured 
as an alternative to guaranteeing governance, with an enduring and sustainable character, of the long-term regional/ local development, creating better quality of life for future generations (Secti, 2011, p. 63).

This finding provides an alert on the need to strengthen, organize and at the same time direct the Pará Innovation System to productive processes based more on knowledge, in line with the wealth generating potential on a regional basis (Sectet, 2015, p. 24).

However, the major funding in the policy at that time was kept associated with the financing modalities related to the awards of grants and support for post-graduation and scientific and technological research. We identified that 48 out of the 124 calls for funding launched by the state FAP between 2008 and 2017, were for scientific and technological research, 19 were for post-graduate program grants, 11 for scientific initiation programs and only six (6) for corporate research and development (R\&D) and innovation.

This observation backs up other studies on the Brazilian ST\&I policy (Dagnino, 2016; Dias, 2012), in which, despite the emphasis in the specific policy on the agenda for technological innovation, this emphasis had limited results, tending more to legitimizing public incentives for S\&T. This is because the unfavorable macroeconomic and peripheral national conditions (high interest rates, commodity export-based economy, disarticulation of the industrial policy, and cultural and technological dependence), has implied a low innovation propensity of the local business community. Consequently, the ST\&I policy in Brazil continues under the predominance of actors linked to the research community (Dagnino, 2016), even with the inclusion in the agenda of technological innovation.

Focusing on social inclusion concerns in the ST\&I policy process in Pará, we found four themes in the main government plans: digital inclusion, ST, family farming, and land inequality in investments and ST\&I capacities in the state. With regard to the implementation of the incentive through public calls for funding, we found 11 topics associated with such concerns: digital inclusion, ST, family farming, land inequalities, AT, neglected diseases, gender, children and adolescents, traditional populations, inclusive economy and equitable access to water.

While these topics in general are not central to the policy orientation or substantial financing volume, their emergence is indicative of including new topics in the policy agenda. We selected two from among those topics for specific analysis.

The ST topic was present in guiding documents of the ST\&I policy beginning in 2011 and was the only one with funding through an open call from the state Secretariat, where there was an administrative unit dedicated to the topic. We therefore understand that its actors may have found an institutionalization strategy alongside the more traditional decision-making bodies in the ST\&I state policy.

The AT topic was not mentioned in the explicit policy-oriented documents, but was the subject of two exclusive FAP calls for funding and a thematic line of another two, which may indicate that their policy actors had sought alternative strategies to achieve the agenda. 


\subsection{The state policy subsystem for assistive technology (AT)}

An AT policy on the ST\&I state agenda in Pará first emerged in 2011 and was consolidated in 2013, with the launch of the first specific call for AT development funding by the state FAP (no. 010/2013) as part of an intersectoral program.

We understand that the key actor in achieving the agenda was a researcher who already had been a care worker for people with disabilities. In 1997, she founded the Amazon Association of Care for the Disabled Child (ACDA) and since the mid-2000s has been coordinating an AT center (Nedeta) at Pará State University (UEPA), which is being set up with funding from federal agencies (Finep and $\mathrm{CNPq}$ ).

Since 2006, this researcher had been organizing biannual forums on the AT issue through Nedeta. In 2011, she successfully raised funds to organize the $1^{\text {st }}$ Pará Fair on Assistive Technology, Accessibility and Social Inclusion of People with Disabilities held on the premises of the state's Secretariat for Social Welfare. The researcher chose this venue in order to further awareness and articulation with key people in the state government, and even the state governor visited the fair.

That same year, the federal government launched the National Plan of Rights for People with Disabilities (PNDPcD) (decree no. 7612/2011), which provided visibility of the policies to ensure rights for the people with disabilities (including AT), and also began decentralizing actions for the state and municipal governments. This convergence between incentives outside the PNDPcD subsystem and local AT initiatives helped the formulating the Existir Plan (state program articulated to PNDPcD) and the state governor's commitment to this incentive plan for funding the AT development within the ST\&I.

Through the state FAP funding call no. 010/2013, 15 AT projects were funded (five associated to Nedeta). In 2016, the following events were held: $1^{\text {st }}$ Existir State Fair; $2^{\text {nd }}$ Pará Fair on Assistive Technology, Accessibility and Social Inclusion of People with Disabilities, and the $5^{\text {th }}$ Forum of Assistive Technology and Social Inclusion of People with Disabilities. And in 2017, the second exclusive call for AT funding (no. 012/2017) was launched.

We consider that the researcher in question is characterized as an AT policy entrepreneur, whether in advocating ideas or in her role on many fronts for change in the policy process and achieving the agenda (Béland \& Cox, 2015; Capella, 2016).

Given the marginality of AT in the ST\&I agenda, the policy entrepreneur found support in the social welfare policy subsystem and in the head of the state Executive (state governor). Thus, she linked up with other subsystems to influence the ST\&I state policy process and seized the opportunity to use the ascension of the issue to the federal policy agenda.

In addition to coordinating actions for AT funding, there was also the continued organization of spaces for interaction, sharing beliefs and learning (forums, fairs and co-authorship of books) in the specific subsystem in progress, whose key role is also credited to the same entrepreneur of the aforementioned policy.

Before the AT development issue reached the state agenda, we were unaware of the prior existence of its advocacy coalition. The call for funding increased the number of local actors who were involved. The organization of forums (academic and policy) has led to the learning and aggregation of a considerable number of these researchers around Nedeta. Therefore, we understand that the path 
of the AT promotion policy subsystem has provided incentives to form and strengthen an advocacy coalition for AT in the state.

In terms of the belief systems related to AT development, we find that researchers tend to associate with the so-called social model of disability (Garcia, 2014). Yet we note a deployment of this model in two directions with different emphases, one for market mechanisms (which we call technological-marketing emphasis) and the other for more socially plural mechanisms (called social emphasis), as shown in Box 2.

\section{BOX 2}

\section{SUMMARY OF MAIN POINTS OF AT CONCEPT WITH TECHNOLOGICAL-MARKETING} EMPHASIS AND SOCIAL EMPHASIS

\begin{tabular}{|c|c|c|}
\hline Belief elements & AT concept of technological-marketing emphasis ${ }^{1}$ & AT concept of social emphasis \\
\hline Main focus & $\begin{array}{l}\text { Inadequate access for the population that needs } \\
\text { AT due to a divergence between objectives } \\
\text { and capacities of these people and the existing } \\
\text { resources in the environment and "medicalization", } \\
\text { which leads to segregation and high levels of } \\
\text { poverty in this population }\end{array}$ & $\begin{array}{l}\text { Restricted access of the population that needs AT, due } \\
\text { to a divergence between a relative restricted demand } \\
\text { (purchasing power) and a large group of needs unmet } \\
\text { and unable to be met by market conditions due to this } \\
\text { population's high level of poverty }\end{array}$ \\
\hline $\begin{array}{l}\text { Concept of } \\
\text { technology }\end{array}$ & $\begin{array}{l}\text { Development of technology directed at consumer } \\
\text { expectations and needs; by a market-guided } \\
\text { system }\end{array}$ & $\begin{array}{l}\text { Technology developed with guidelines for low-cost } \\
\text { criteria or economically accessible and interacting } \\
\text { with the user. }\end{array}$ \\
\hline $\begin{array}{l}\text { Who produces } \\
\text { knowledge \& } \\
\text { technology }\end{array}$ & $\begin{array}{l}\text { Scientists, engineers and people with disabilities, } \\
\text { as consumers }\end{array}$ & $\begin{array}{l}\text { Scientists, engineers and people with disabilities, as } \\
\text { citizens }\end{array}$ \\
\hline $\begin{array}{l}\text { Policy } \\
\text { protagonists }\end{array}$ & Scientists, government and businesses & $\begin{array}{l}\text { Scientists, government, companies, people with } \\
\text { disabilities and representative organizations }\end{array}$ \\
\hline $\begin{array}{l}\text { Implementation } \\
\text { strategy }\end{array}$ & $\begin{array}{l}\text { Removal of systemic and structural barriers, by } \\
\text { internalizing a consumer "status" and externalizing } \\
\text { the action of procuring resources }\end{array}$ & $\begin{array}{l}\text { Political and social engagement of a person with } \\
\text { disabilities, by internalizing a citizen "status" and } \\
\text { externalizing the action of seeking equal rights }\end{array}$ \\
\hline $\begin{array}{l}\text { Technology } \\
\text { dissemination }\end{array}$ & Supply of goods and services via market & $\begin{array}{l}\text { Multiple dissemination channels, including public and } \\
\text { cooperative }\end{array}$ \\
\hline
\end{tabular}

${ }^{1}$ Elements partly inspired by certification program in applications of assistive technology of the California State University Northridge quoted in Coordenadoria Nacional para Integração da Pessoa Portadora de Deficiência (2009).

Source: Elaborated by the authors. 
Most projects promoted by the funding call in 2013 developed AT applications with concern to be economically feasible and may be disseminated through public policies or free channels, even though such conditions were not required in that call. We also found that nine out of the fifteen projects achieved the development of AT goods or services effectively applied to the target group (a condition also not required under the call). In all these projects with services provided, dissemination channels were used via free or public utilities. No project was developed in partnership with a company or had later transferring of technologies to companies. This would tend to characterize them as predominantly a socially oriented concept.

However, the participation of people with disabilities in such projects was mainly in the role of beneficiaries or users of goods and services. We found no projects where people with disabilities or their representative organizations had taken part in the formulation or $R \& D$ teams. Nor was there any record that they had participated in occasions of formulation or evaluation of the call for funding with FAP. The project teams were mostly made up only of researchers and the planned evaluation process based on peer-reviewed study reports.

These characteristics restrict social inclusion processes through political and social engagement of people with disabilities (McLachlan et al., 2018). In light of that, we must agree with Garcia (2014) that there is still major stress between practices valorized by the social disability framework and the institutionalized practices of research and ST\&I policy in Brazil. Since the latter remain mostly centered on researchers, there are obstacles to other actors participating, including their target groups, namely people with disabilities.

We understand that the AT is an area of research in the early stages of development in the organizations of the S\&T state complex. Many researcher interviewees have joined the domain after the 2013 funding call, and are in a learning process. According to the interviews with those researchers, there were few expressions of conflicting beliefs in the policy. These tended to less diverging positions of the predominantly established R\&D practices, mainly due to absence of tensioning about the limited participation of people with disabilities.

In short, the AT state policy in Pará begins in a chain reaction of external events mobilized by internal actors, especially one policy entrepreneur. The policy entrepreneur successfully promotes the AT issue in the agenda policy. Additionally, in the ACF analysis two entrepreneurial roles also emerged, particularly the promotion and maintenance of forums for sharing beliefs and learning processes (Weible et al., 2009) and the coordination of collective actions related to a network for AT development projects associated with its center. These aspects resemble the elements highlighted by Mintrom and Norman (2009), and we stress particularly team building in the case of the advocacy coalition.

The longer-term analysis associated with ACF, when applied to the view of the entrepreneur's performance, also demonstrates the policy resources accumulated by him or her as time passes (material resources such as funding, social resources such as reputation) in order to articulate them at the right time when appearing on the agenda. Moreover, it helps to observe a continuing role throughout the policy process (not only in agenda setting), and in implementing programs and projects. 


\subsection{The state policy subsystem for social technology (ST)}

The policy process for promoting ST appeared in the ST\&I state agenda in Pará in 2011 with its inclusion in the ST\&I program of the state pluriannual plans (PPA) and ST\&I Master Plan. In 2012 the Social Technology Directorate (STD) was implemented into the structure of the state Secretariat. A key role in this ascension was credited to the head of the Secretariat who proposed the topic in the policy plans and underpinned the structure of the Directorate.

After this emergence, we identified two different periods in the course of the ST policy process in the state government. The first, from 2011 to 2014, developed from the STD structure and was emphasized in a promotion of the ST policy by institutionalizing the ST Network in Pará (RTS-PA), along the lines of the national ST Network (RTS Brazil). In this regard, state-level ST forums were held and a reference document for the RTS-PA was drafted in order to structure specific governance for the ST state policy.

At that time, we noted a deep concern with the conceptual framework for ST and its alignment to the agreed upon concept in RTS Brazil. We interpreted, on one hand, that this alignment corresponded to the affiliation of beliefs of the main local actors involved. On the other hand, such association with the national concept was also a strategy for legitimizing the domain with regard to other actors from the research community and the ST\&I state policymakers.

Although the actors do not report federal government induction to the ascension of ST to the state agenda, they admit to having mobilized learning processes in relation to the national RTS in order to organize the RTS-PA structure and governance and ST state forums. In addition, research groups and civil society organizations (CSO) involved in ST projects funded by the federal government were invited to participate in these forums.

Nevertheless, it should be stressed that the beliefs relating to the ST concept of the main actors involved in such actions diverged from the prevailing beliefs of the ST\&I policy, represented in the main direction of the technological innovation policy, as summarized in Box 3.

BOX 3

SUMMARY OF THE MAIN CONCEPTUAL POINTS OF THE PREVAILING ST\&I POLICY AND THE ST POLICY CONCEPT AT THE FIRST MOMENT OF THE STUDIED PATH

Elements of beliefs
$\begin{aligned} & \text { Main focus } \\ & \text { Technological innovation creates economic Social exclusion processes are structural. So, } \\ & \text { development (due to competitiveness and productive and social inclusion covers alternative } \\ & \text { added value) that overflows social benefits by technological developments adapted to reality and } \\ & \text { improving jobs, professional qualification and local social groups } \\ & \text { new products }\end{aligned}$




\begin{tabular}{|c|c|c|}
\hline Elements of beliefs & Predominant concept in the ST\&I state policy & Concept of the social technology policy ( $1^{\text {st }}$ moment) \\
\hline Concept of technology & $\begin{array}{l}\text { Technology developed predominantly based on } \\
\text { advanced scientific knowledge }\end{array}$ & $\begin{array}{l}\text { Technology developed by interaction with social } \\
\text { community or group, based on different types of } \\
\text { knowledge including the popular and traditional }\end{array}$ \\
\hline $\begin{array}{l}\text { Producers of } \\
\text { knowledge, technology } \\
\text { and innovation }\end{array}$ & $\begin{array}{l}\text { Scientists, engineers and entrepreneurs/ } \\
\text { business people }\end{array}$ & $\begin{array}{l}\text { Scientists and different social actors through } \\
\text { knowledge networks }\end{array}$ \\
\hline Policy protagonists & Scientists, government and companies & $\begin{array}{l}\text { Scientists, government, companies, CSO and local } \\
\text { social groups and communities }\end{array}$ \\
\hline Implementation strategy & $\begin{array}{l}\text { Emphasis on traditional organizations of the } \\
\text { productive sector, companies and industrial } \\
\text { agglomerates }\end{array}$ & Emphasis on cooperatives or associations \\
\hline $\begin{array}{l}\text { Technological } \\
\text { dissemination }\end{array}$ & Technology transfer & Reapplication and sociotechnical adaptation \\
\hline
\end{tabular}

Source: Elaborated by the authors.

This divergence of beliefs caused stress in the ST policy and led the theme to a marginal position in conceptual and material terms, in the domain of a state ST\&I. Thus, despite the presence in the explicit policy at that time (2011-2014) there was no relevant state funding for ST projects. Only two small investments for community projects were identified in 2012.

The second stage in the course of the ST policy brought a new institutional design in the period 2015-2017. In 2015 the state Secretariat was no longer dedicated solely to ST\&I, which resulted in budget restraints for the domain and further tightening of its internal resources. The ST agenda was maintained but the previously structures (TSD, forums and RTS-PA) were overlooked. The topic was allocated at the level of a coordinating body of the Secretariat (Coordination of Technology for Social Development) subordinate to the S\&T Directorate, with friction between the predominant beliefs of the Directorate sectors and those involved with ST.

The main implementation instrument for promoting the ST policy was the funding of ST projects based on the conventional S\&T research format, coordinated by researchers linked to universities. Four projects were funded over the period, with the decision-making centered on the Secretariat structure.

Among the projects funded, we found that actors of the executive team of three presented a similar ST concept or with reports of learning linked to the second column in Box 3, mainly with regard to the importance of technological development by interacting with local communities. Another project, although focused on attending underprivileged populations, adopted a technological concept in line with that predominant in the ST\&I policy (first column of Box 3).

Although we found actors with similar beliefs working on projects funded in the state subsystem, they reported no interactions between each other. Consequently, we did not find collective action 
coordination between them that could characterize a developing advocacy coalition. From the typology of Weible et al. (2019) the situation portrayed a latent or disconnected coalition.

In 2017, the State Council of the S\&T approved a resolution (Consectet no. 003/2017) dedicated to the ST state policy, which imposed a new set of guidelines. These guidelines showed a closer approach to the concepts and instruments prevailing in the ST\&I policy. The governance structure and instruments of the ST policy were directed towards the decision-making centers of the Secretariat and its associate organizations (FAP and S\&T Park).

This resolution was again credited as an initiative of the same Secretariat officer. We understand that this action was designed to establish a reasonable level of commitment in developing the ST policy by legitimizing it in the general institutional bodies of the state ST\&I. When the ST policy guidelines came closer to those predominant in the general ST\&I policy, the divergences were reduced between the prevailing concepts and instruments of the general ST\&I policy and those of the ST policy. The role of this officer matches the policy broker described by Sabatier and Jenkins-Smith (1993). It is worth mentioning that the beliefs of this officer's policy were affiliated to the prevailing concept in ST\&I state policy.

Despite this strategy of the policy broker having contributed to a certain extent to the institutionalization of the ST on the state agenda, it also allowed a wider variety of actors' beliefs within the specific ST subsystem, which could lead to greater competition for funding. This, in fact, makes it possible for actors with beliefs closer to the prevailing ST\&I advocacy coalition to capture the ST domain. Thus, there was a drop in potential ST conflicts with the prevailing ST\&I policy, but the ST subsystem opens up major potential for internal divergence from ST-related beliefs.

In short, the policy broker help to raise the ST issue to the agenda and favored formation of the specific ST subsystem. However, he did not act directly on an ST advocacy coalition building activity (establishing belief-sharing mechanisms or coordinating collective actions).

In the first stage of the policy course, incentives were provided to structure a bureaucratic body dedicated to the policy (STD) and articulations for sharing beliefs and knowledge about ST (RTS-PA and forums). These initiatives could, at a later date, enhance the advocacy coalition formation and emergence of entrepreneurs bound by it, but they were not enduring enough to do so.

In the second stage, the policy broker was successful in institutionalizing the ST policy with the higher ST\&I body, and in reducing the divergences of concepts and instruments. However, no local ST advocacy coalition was observed. To some extent, this could be related to the absence of forums, increase in internal competition for resources between the actors in the ST subsystem, and the absence between actors with similar beliefs of the ST policy that would be dedicated to working as policy entrepreneurs, including in advocacy coalition formation and development. 
RAP | Advocacy coalition formation and key actors within the policy

\section{CLOSING REMARKS}

This article analyzed the advocacy coalition formation and the roles of key actors, based on the AT and ST policy processes in the ST\&I domain in a subnational context. Both policy processes analyzed correspond to marginal agendas of social inclusion by the ST\&I, but present different performances and key actor roles.

In both cases analyzed, the key actors played a leading role in the emergence of the policy subsystems (AT and ST), but had different interactions in the advocacy coalition formation. In the AT case, the policy entrepreneur had a key role to achieve and maintain the item on the agenda and was positively associated with the advocacy coalition formation. For that association playing roles for both defense of the issue on the agenda, promoting regular mechanisms of sharing beliefs and learning (organizing events and book anthologies), and also coordinating collective actions of its members (proposal of projects and demands for new funding), and achieving a position of scientific recognition and a policy of specialization on the issue over time (resources and stability).

In the case of ST, we saw no developing advocacy coalition, and no actor with characteristics associated with the roles of systematic articulation for an advocacy coalition formation in the policy.

The cases analyzed show that the inclusion of the policy entrepreneur category sheds light on details of how and when changes in the policy process occur and its incidence in the advocacy coalition formation. The analysis of the policy entrepreneur from the analytical ACF viewpoint conveys a long-term view of its role. This demonstrate how it accumulates resources, achieves stabilization and knowledge and builds strategies. Just as it implies a concept of the policy entrepreneur closely associated with the conceptualization of advocacy coalitions (due to protagonism of this concept in the ACF), which highlights aggregation characteristics of allies by belief sharing, creating policy-oriented forums and learning mechanisms, and systematically coordinating collective actions in the subsystem. 


\section{REFERENCES}

Béland, D., \& Cox, R. H. (2016). Ideas as coalition magnets: coalition building, policy entrepreneurs, and power relations. Journal of European Public Policy, 23(3), 428-445. Retrieved from https://doi. org/10.1080/13501763.2015.1115533

Capella, A. C. N. (2016). Um estudo sobre o conceito de empreendedor de políticas públicas: ideias, interesses e mudanças. Cadernos EBAPE. $B R, 14$ (spe), 486-505. Retrieved from http://dx.doi. org/10.1590/1679-395117178

Capella, A. C. N., \& Brasil, F. G. (2015). Análise de políticas públicas: uma revisão da literatura sobre o papel dos subsistemas, comunidades e redes. Novos estudos CEBRAP, 101, 57-76. Retrieved from http:// dx.doi.org/10.1590/S0101-33002015000100003

Cavalcante, L. R. (2011). Desigualdades regionais em ciência, tecnologia e inovação (CT\&I) no Brasil: uma análise de sua evolução recente (Texto para Discussão, No. 1574). Brasília, DF: Instituto de Pesquisa Econômica Aplicada.

Coordenadoria Nacional para Integração da Pessoa Portadora de Deficiência. (2009). Tecnologia Assistiva. Brasília, DF: Subsecretaria Nacional de Promoção dos Direitos da Pessoa com Deficiência.

Dagnino, R. (2016). A Anomalia da Política de C\&T e sua Atipicidade Periférica. Revista Iberoamericana de Ciencia, Tecnología y Sociedad-CTS, 11(33), 33-63. Retrieved from http://dx.doi.org/10.1590/S010269092014000300004

Dias, R. de B. (2012). Sessenta anos de política científica e tecnológica no Brasil. Campinas, SP: Editora Unicamp.

Faria, C. A. P. (2003). Ideas, knowledge and public policies: a brief inventory of the latest main analytical approaches. Revista Brasileira de Ciências Sociais, 18(51), 21-30. Retrieved from http://dx.doi. org/10.1590/S0102-69092003000100004

Garcia, J. C. D. (2014). Deficiência e Tecnologia Assistiva: Conceitos e Implicações para as Políticas Públicas. In Proceedings of $1^{\circ}$ International Assistive Technology Symposium (pp. 69-85), Campinas, SP.

Jenkins-Smith, H. C., Nohrstedt, D., Weible, C. M., \& Sabatier, P. A. (2014). The advocacy coalition framework: Foundations, evolution, and ongoing research. In P. Sabatier, \& C. Weible (Ed.), Theories of the policy process, ( ${ }^{a}$ Ed., Cap. 6, pp. 183-224). Boulder, CO: Westview Press.

Jenkins-Smith, H. C., Nohrstedt, D., Weible, C. M., \& Ingold, K. (2017). The advocacy coalition framework: An overview of the research program. In P. Sabatier, \& C. Weible (Ed.), Theories of the policy process (4a Ed., Cap. 5, pp. 135-171). New York, NY: Routledge.

Kingdon, J. W. (2014). Agendas, alternatives, and public policies. Harlow, Essex: Pearson Education Limited.

Law no. 7,077 (2020). Anexo Programa Finalístico. Belém, PA: Diário Oficial do Estado do Pará.

Leifeld, P. (2013). Reconceptualizing major policy change in the advocacy coalition framework: A discourse network analysis of German pension politics. Policy Studies Journal, 41(1), 169-198. Retrieved from https://doi.org/10.1111/psj.12007

MacLachlan, M., Banes, D., Bell, D., Borg, J., Donnelly, B., Fembek, M. ... Hooks, H. (2018). Assistive technology policy: a position paper from the first global research, innovation, and education on assistive technology (GREAT) summit. Disability and Rehabilitation: Assistive Technology, 13(5), 454466. Retrieved from https://doi.org/10.1080/17483 107.2018.1468496

Mintrom, M., \& Norman, P. (2009). Policy entrepreneurship and policy change. Policy Studies Journal, 37(4), 649-667. Retrieved from https://doi. org/10.1111/j.1541-0072.2009.00329.x

Mintrom, M., \& Vergari, S. (1996). Advocacy coalitions, policy entrepreneurs, and policy change. Policy studies journal, 24(3), 420-434. Retrieved from https://doi.org/10.1111/j.1541-0072.1996. tb01638.x

Ragin, C. C. (1992). "Casing" and the process of social inquiry. In C. C. Ragin \& H. S. Becker (Ed.), What is a case? Exploring the foundations of social inquiry (Cap. 10, pp. 217-226) New York, NY: Cambridge University Press.

Ragin, C. C. (2009). Reflections on casing and caseoriented research.In D. Byrne \& C. C. Ragin (ed.) The Sage handbook of case-based methods (cap. 31, pp. 522-534). London, UK: Sage Publications. 
Rede de Tecnologia Social (Org.). (2010). Tecnologia Social e Desenvolvimento Sustentável. Brasília/DF: Secretaria Executiva da RTS.

Sabatier, P. A., \& Jenkins-Smith, H. C. (1993). Policy change and learning: An advocacy coalition approach. Boulder, CO: Westview Press.

Secretaria de Estado de Ciência, Tecnologia e Educação Técnica e Tecnológica. (2015). Plano Diretor 2015-2019: Plano de CT\&I e Educação Profissional e Tecnológica. Belém, PA: SECTET. Retrieved from https://issuu.com/sectipa/docs/ plano_diretor_sectet_2015-2019/1

Secretaria de Estado de Ciência, Tecnologia e Inovação. (2011). Visão Estratégica: Plano Diretor de Ciência, Tecnologia 2011/2015. Belém, PA: SECTI,
2011. Retrieved from https://issuu.com/sectipa/ docs/planodiretorsecti

Theis, I. M., Strelow, D. R., \& Lasta, T. T. (2017). CT\&I e desenvolvimento desigual no Brasil: é possível outro "modelo de desenvolvimento"? Revista Tecnologia e Sociedade, 13(27), 43-61. Retrieved from http://dx.doi. org/10.3895/rts.v13n27.3637

Weible, C. M., Sabatier, P. A., \& McQueen, K. (2009). Themes and variations: Taking stock of the advocacy coalition framework. Policy Studies Journal, 37(1), 121-140. Retrieved from https://doi.org/10.1111/ j.1541-0072.2008.00299.x

Weible, C. M., Ingold, K., Nohrstedt, D., Henry, A. D., \& Jenkins-Smith, H. C. (2019). Sharpening advocacy coalitions. Policy studies journal. Retrieved from https://doi.org/10.1111/psj. 12360

\section{Diana Cruz Rodrigues}

https://orcid.org/0000-0001-6670-8907

Ph.D. in Administration; Professor at University of Amazon (UNAMA) in the Administration Postgraduate Program. E-mail: dicruzrodrigues@gmail.com

\section{Mário Vasconcellos Sobrinho}

https://orcid.org/0000-0001-6489-219X

Ph.D. in Development Studies; Professor at University of Amazon (UNAMA) in the Administration Postgraduate Program and at Federal University of Pará (UFPA) in the Natural Resources Management and Local Development in Amazon Postgraduate Program. E-mail: mario.vasconcellos@unama.br

\section{Ana Maria de Albuquerque Vasconcellos}

https://orcid.org/0000-0002-7594-3578

Ph.D. in Development Studies; Professor at University of Amazon (UNAMA) in the Administration Postgraduate Program. E-mail: anamaria.vasconcellos@unama.br 